
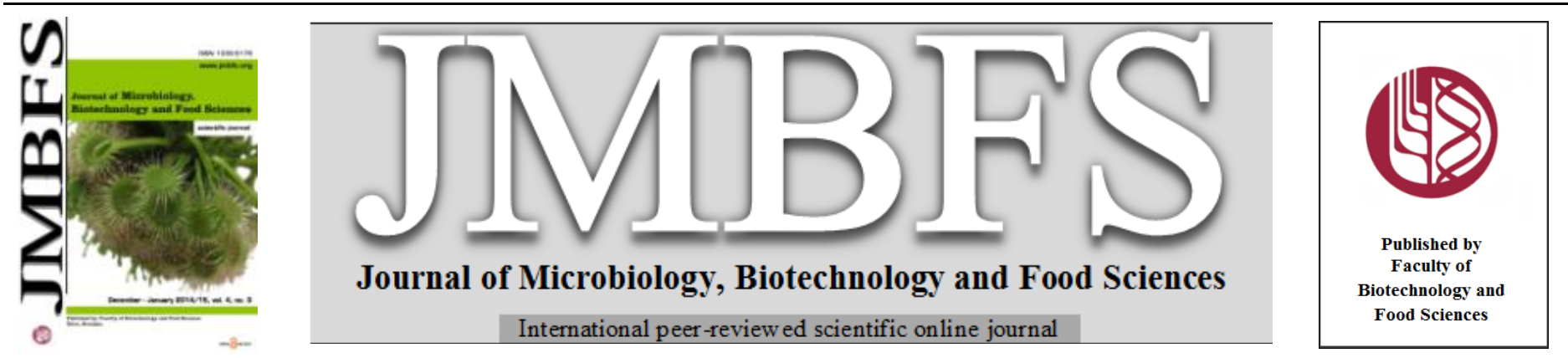

\title{
PARTIAL CHARACTERIZATION OF A LYTIC METHICILLIN RESISTANT-STAPHYLOCOCCUS AUREUS BACTERIOPHAGE
}

\author{
Sulaiman Al-Yousef* \\ Address(es): University of Dammam, College of Applied Medical Science, Department of Medical Laboratory Technology, 1704, Hafr Al Batin-319 91, Saudi Arabia.
}

*Corresponding author: saalyousef@ud.edu.sa

doi: 10.15414/jmbfs.2014-15.4.3.194-197

\section{ARTICLE INFO}

Received 7. 9.2014

Revised 25. 9. 2014

Accepted 25. 9. 2014

Published 1. 12. 2014

Regular article

OPEN $\partial_{\text {ACCESS }}$

\begin{abstract}
A marked increase in the infection incidence caused by methicillin-resistant Staphylococcus aureus (MRSA) strains has been noted in medical practice in recent years. This study was conducted to study the biological and characterize of MRSA-phage. Methicillin resistance of Staphylococcus aureus was detected and confirmed by determining of the MIC of oxacillin by the standard agar dilution method. Phage was biologically purified using single plaque technique, then phage characterization were studied using host range, adsorption time, particle morphology and its structural protein. MRSA phage showing lytic nature was purified by repeated plating after picking of single isolated plaques. This phage is active against all 11 isolates either of $S$. aureus or MRSA tested as hosts. Phage produced clear plaques indicating their lytic nature. This phage was concentrated employing polyethylene glycol (PEG)-NaCl precipitation method. Morphologically, MRSA Phage has a hexagonal head having a long non-contractile tail, indicating his icosahedral nature. Adsorption studies showed 100\% adsorption of MRSA-Phage after 35 minutes of exposure. Sodium dodecyl sulfatepolyacrylamide gel electrophoresis (SDS-PAGE) experimentation indicated that the phage particles contain one major structural protein (about $30 \mathrm{Kda}$ ).
\end{abstract}

Keywords: MRSA, phage, concentration, characterization

\section{INTRODUCTION}

Staphylococcus aureus (S. aureus) is a versatile pathogenic bacterium (Schmidt et al., 2010) responsible for a significant number of heal thcare-associated and community-acquired infections (Kurlenda and Grinholc, 2010). It causes a broad spectrum of infections ranging from acute to chronic disease (Van den Berg et al., 2011 and Francois et al., 2010) and is a common etiological agent of opportunistic infections. It is well known that the organism acquires resistance soon after the introduction of new antibiotics (Lyon and Skurray, 1987) Methicillin was developed in 1960 for the treatment of such multidrug resistant Staphylococcus aureus. However in the same year, Jevons (1961) discovered Methicillin Resistance $S$. aureus (MRSA), which by 1970s has become spread all over the world. There was a new interest in the possibilities of bacteriophage therapy, which a specific kind of viruses that attack only bacteria used to kill the pathogenic microorganisms (Barrow and Soothhill, 1997). Duckworth and Gulig, 2002 showed that phage therapy would have a role against infectious diseases. Although bacteriophages had not been extensively used as antimicrobial agents since the emergence of antibiotics, the rise of multiple antibiotic resistant strains had a renewed in phage therapy (Platt et al., 2003). Amenu, (2014) examine various aspects of bacteriophage ecology, particularly focusing on phages specific to the bacterial species Staphylococcus aureus, Pseudomonas aeruginosa, and Escherichia coli. Basdew and Laing (2014) studied sensitivity of six S. aureus-phage isolates towards simulated environmental. Three of the six isolated phages performed optimally during the in vitro assays and have considerable potential for in vivo applications. Recently, some Staphylococcal phages have been isolated and characterized (Gu et al., 2012; Cui et al., 2012; Amenu, 2014; Swift and Nelson, 2014; El Haddad et al., 2014; Li and Zhang, 2014). Our study was performed to complete the previous work (Al-Yousef, 2013). Also, objectives of the present work were to study biological and partial characterize of MRSA-phage.

\section{MATERIAL AND METHODS}

\section{Staphylococcus aureus and bacteriophage}

Methicillin-Resistant $S$. aureus (MRSA) strain and their specific bacteriophage was obtained from previous work (Al-Yousef, 2013). Methicillin resistance of $S$. aureus was determined by MRSA screening agar containing $6 \mu \mathrm{g} / \mathrm{ml}$ oxacillin. Confirmation for methicillin resistance was performed by determining the oxacillin-MIC by the standards of antimicrobial susceptibility testing according to CLSI, 2013 and MicroScan ${ }^{\mathbb{B}}$ instrumentation (Siemens Healthcare Diagnosis Inc, USA) (Barry, 2007). Bacteriophage stocks were generated by combining $500 \mu \mathrm{L}$ of MRSA culture with $500 \mu \mathrm{L}$ of each bacteriophage $\left(1.0 \times 10^{6} \mathrm{PFU} \mathrm{mL} \mathrm{m}^{-1}\right)$ in a test tube, pouring the contents onto a tryptic soy agar plate, and incubating the plate overnight at $37{ }^{\circ} \mathrm{C}$. Following incubation, the plate's content was collected into a $50 \mathrm{~mL}$ tube by washing with tryptic soy broth (TSB), scraping with a sterile plastic loop, and aspirating with a pipette. The tube was then centrifuged for 20 minutes at $3500 \mathrm{rpm}$ to pellet out the debris, and the supernatant was filtered through $0.2 \mu \mathrm{m}$ Millipore membrane to remove extraneous debris. The final phage filtrate was quantified using a traditional plaque assay (Adams, 1959).

\section{Plaque purification and lysate preparation}

A single plaque was picked from the plate with a sterile tooth-pick, introduced into $3 \mathrm{ml}$ of a log phase culture of the MRSA host in nutrient broth, and was incubated at $37^{\circ} \mathrm{C}$ in an environmental shaker at $120 \mathrm{rpm}$ for 12 hours. This was then centrifuged at $10.000 \mathrm{~g}$ followed by filtration through $0.22 \mu \mathrm{m}$ Millipore membrane. The lysate obtained was used for double agar overlay. This procedure was repeated 6 times, until uniform sized plaques were obtained on the plate. The plates with uniform sized plaques were overlaid with $10 \mathrm{ml}$ of SM buffer solution $[100 \mathrm{mM} \mathrm{NaCl}, 10 \mathrm{mM} \mathrm{MgSO} 4,50 \mathrm{mM}$ Tris- $\mathrm{HCl}, \mathrm{pH} 7.5$ and $0.01 \%(\mathrm{w} / \mathrm{v})$ gelatin] and were incubated overnight at $4{ }^{\circ} \mathrm{C}$, with gentle rocking so that phages could easily diffuse into the buffer. The phage suspension was recovered after incubation from all the plates and pooled. Chloroform was added to this pooled mixture to a final concentration of $5 \%(\mathrm{v} / \mathrm{v})$, mixed well using a vortex mixer and incubated at room temperature for 15 minutes. The cell debris was then removed by centrifugation at $5000 \mathrm{~g}$ for 10 minutes (Sigma, 3K30, Germany) and the supernatant was transferred to sterile polypropylene tube. Chloroform was added to a final concentration of $0.3 \%(\mathrm{v} / \mathrm{v})$ and this was stored at $4^{\circ} \mathrm{C}$ until use The titer of this lysate was noted after serial dilution according to Malke, (1990). 


\section{Host range determination}

Spot tests were used for host range studies, and, in all cases, positive tests were confirmed by plaque assay. Eighteen bacterial isolates, (6 MRSA; $5 \mathrm{~S}$. aureus; 2 Pseudomonas aeruginosa; 2 Klebsiella pneumonia and 3 Escherichia coli) (Table 1) were used as indicators for the determination of phage sensitivity by an agar spotting method (Adams, 1959). Ten microliters from bacteriophage samples $\left(10^{9} \mathrm{PFU} / \mathrm{ml}\right)$ were placed on each lawn of indicator cells and left to stand for 30 min. Plaque formation was examined for lysis after $24 \mathrm{~h}$ incubation at $37^{\circ} \mathrm{C}$. The results were recorded as positive (+) and negative (-).

\section{Phage adsorption}

The first step in the growth of bacteriophage was its attachment to susceptible bacteria, this process is called adsorption. Log phase culture of host was infected using the phage then incubated at $37^{\circ} \mathrm{C}$. Aliquots of $5 \mathrm{ml}$ were sampled at 0,5 , $10,15,20,25,30,35,40$ and 45 minutes time intervals after infection. All the samples drawn were immediately filtered through $0.22 \mu \mathrm{m}$ membrane filter (Millipore, USA). The phage titer was determined using double agar overlay method after appropriate dilutions. All plating was done in triplicates and appropriate controls were maintained. The percentage of phage adsorption was calculated as follows: [(control titer -residual titer)/control titer] X $100 \%$ (Durmaz et al., 1992). The phage titer observed at time zero was considered as the control titer.

\section{Phage concentration}

Phage was concentrated using Polyethylene glycol (PEG) 6000 as described by Malke, (1990). Briefly, $1 \%(\mathrm{v} / \mathrm{v})$ of an overnight culture of the host bacteria was transferred to $200 \mathrm{ml}$ nutrient broth, and incubated at $37^{\circ} \mathrm{C}$ for 3 hours in an environmental shaker at $100 \mathrm{rpm}$. Phages were added and the incubation at $37^{\circ} \mathrm{C}$ was continued at $100 \mathrm{rpm}$ for 12 hours. This broth was then centrifuged at 8000 rpm for 20 minutes (Sigma, 3K30, Germany), the supernatant was collected and filtered through $0.22 \mu \mathrm{m}$ membrane Millipore filter. Solid $\mathrm{NaCl}$ was added to a final concentration of $1 \mathrm{M}$ and dissolved by stirring with a sterile glass rod. This mixture was kept in ice for 1 hour, followed by centrifugation at $9000 \mathrm{rpm}$ for 10 minutes at $4^{\circ} \mathrm{C}$. Solid PEG 6000 was added to the supernatant at a final concentration of $10 \%(\mathrm{w} / \mathrm{v})$, dissolved by slow stirring on a magnetic stirrer at room temperature. This was then kept in ice overnight, followed by centrifugation at $9000 \mathrm{rpm}$ for 10 minutes at $4^{\circ} \mathrm{C}$. The supernatant was discarded completely, while the pellet was resuspended in $5 \mathrm{ml}$ of phosphate buffered saline (PBS). PEG and cell debris were removed from the phage suspension by the addition of an equal volume of chloroform, vortexing for 30 seconds, followed by centrifugation at $2000 \mathrm{rpm}$ for 15 minutes at $4^{\circ} \mathrm{C}$. The aqueous phase containing the phage particles were recovered and stored at $-20^{\circ} \mathrm{C}$. Phage stock was stored with chloroform ( $5 \%$ by volume) at $4{ }^{\circ} \mathrm{C}$, and an aliquot was frozen at $-80{ }^{\circ} \mathrm{C}$ in MRS broth containing $15 \%$ glycerol.

\section{Morphological analysis by transmission electron microscopy (TEM)}

Formvar membrane-coated grids were placed on a drop of bacteriophage diluted with distilled water. The grids were then placed on a drop of $2 \%$ uranylacetate for 10-20 s, lifted and dried with filter paper, then dried in air. The grids were examined using a Hitachi 7100 transmission electron microscope (Joil, model GEM 1010).

Phage structural protein analysis by sodium dodecyl sulfate-polyacrylamide gel electrophoresis (SDS-PAGE)

SDS-PAGE was performed for determining the size and number of the proteins of phage particles. Concentrated and purified sample phage $(0.1-\mathrm{ml})$ was heated at $100^{\circ} \mathrm{C}$ for $5 \mathrm{~min}$ to ensure denaturation before loading on a gel for electrophoresis. Electrophoresis was carried out with a $4 \%$ stacking layer and $12.5 \%$ separating gel according to Laemli (1970). Standard proteins were used as size markers. Each well was loaded with $10 \mu \mathrm{l}$ of sample containing approximately $10 \mu \mathrm{g}$ of protein. Following electrophoresis, protein bands were stained with Coomassie blue R-250 solution, followed by destaining with $7.5 \%$ glacial acetic acid and 5\% methanol, and then photographed.

\section{RESULTS AND DISCUSSION}

A marked increase in the infection incidence caused by MRSA strains has been noted in medical practice in recent years. Colonization with MRSA has been described as a risk factor for subsequent MRSA infection (Davis et al., 2004 and Khairulddin et al., 2004). The prospects of lytic phages as bio-control agents against pathogenic bacteria are being reconsidered worldwide with the surfacing of multiple antibiotic resistances (Sulakvelidze et al., 2001). S. aureus is one among many bacterial pathogens which phages are experimented as therapeutic agents (Leszczyňski et al., 2006). Thus the rationale of the present study was to search for specific lytic phages where it was most likely to be found i.e. from the soil (the same environment where their host $S$. aureus is known to reside) (AlYousef, 2013).

\section{Bacteriophages isolation}

MRSA was the host bacterium that helped to isolate lytic bacteriophage from the soil samples in previous work. The phage was obtained only via the enrichment protocol. MRSA Phage consistently exhibited excellent bacterial cell lysis capability. MRSA Phage was purified by repeated plating and picking of single isolated plaques from the lawns of MRSA plates, and produced clear and round plaques with well-defined edges indicating their lytic nature (Figure 1).

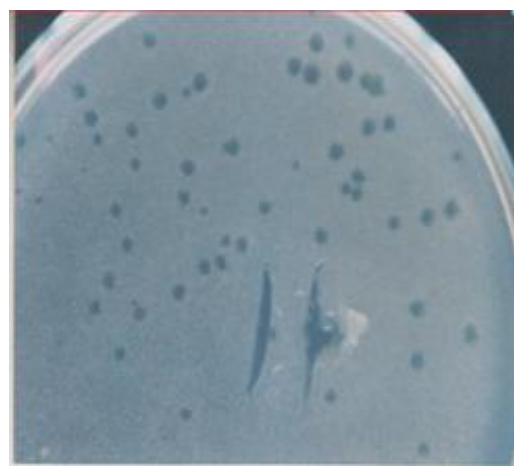

Figure 1 Plate showing plaques formed by Staphylococcus aureus-phage on bacterial lawn of MRSA

\section{Host range}

The host range of MRSA phage was determined with 18 selected isolates from 4 genera. MRSA phage was lytic against both MRSA and S. aureus. The other bacterial isolates were not sensitive to phage (Table 1). Host range within the genus is considered to be a desirable quality of phage as a bio-control agent

\section{Table 1 Host range of MRSA-phage}

\begin{tabular}{lc}
\hline \hline Bacterial isolates & Lysis $^{(\mathrm{a})}$ \\
\hline \hline Methicillin Resistance $S$. aureus (MRSA) & + \\
Methicillin Resistance $S$. aureus (MRSA) & + \\
Methicillin Resistance S. aureus (MRSA) & + \\
Methicillin Resistance $S$. aureus (MRSA) & + \\
Methicillin Resistance $S$. aureus (MRSA) & + \\
Methicillin Resistance $S$. aureus (MRSA) & + \\
S. aureus & + \\
S. aureus & + \\
S. aureus & + \\
S. aureus & + \\
S. aureus & + \\
Pseudomonas aeruginosa & - \\
Pseudomonas aeruginosa & - \\
Klebsiella pneumonia & - \\
Klebsiella pneumonia & - \\
Escherichia coli & - \\
Escherichia coli & - \\
Escherichia coli & - \\
\hline \hline
\end{tabular}

${ }^{a}+=$ Plaques formed; - = no plaque formed

\section{Concentration of MRSA Phage}

As concentration and purification of virus particles are prerequisites for structural and functional characterization of phages (Boulanger, 2009), MRSA phage was purified and concentrated. Concentration was done employing PEG-NaCl precipitation method was as described by Malke, (1990). The efficiency of this method is almost independent of phage concentration and is therefore useful in order to concentrate even phage lysates with very low titer (Yamamoto $\boldsymbol{e t}$ al. 1970). MRSA phage was concentrated up to 1 x $10^{10} \mathrm{PFU} / \mathrm{ml}$ using $\mathrm{PEG}$ precipitation and these phage concentrates prepared in large quantities were used for all further studies.

\section{Characterization of isolated MRSA-phage}

\section{Morphological analysis by TEM}

The TEM was employed to aid in this morphological analysis. The morphtypes exhibited by MRSA-phage have been previously reported in association with genus Staphylococcus. There are prior reports on Staphylococcus phages belonging to families Podoviridae and Siphoviridae (Aswani et al., 2011). The TEM image of our MRSA phage isolate revealed identical bacteriophage with a 
hexagonal head ( $64 \pm 2 \mathrm{~nm}$ ) having a long non-contractile tail (132 $\pm 2 \mathrm{~nm})$, which are typical morphological features of family Myoviridae (Figure 2).

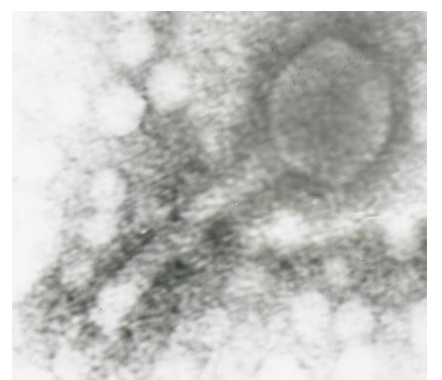

Figure 2 Transmission electron micrograph image of phage stained with $2 \%$ uranyl acetate MRSA phage.

\section{Phage adsorption}

Phage adsorption on to the susceptible host is the second significant factor affecting the successful phage-host interaction. Adsorption is described as the first step of phage infection and may be defined as the attachment of phage particles to bacterial surfaces so that phage and bacteria can sediment togethe (Adams, 1959). The phage extracellular search is a time of free diffusion that delays the onset of virus attachment (Shao and Wang, 2008). Careful determination of the time taken by the phages to adsorb onto to the host cell is of paramount importance, as it may serve in later experiments for accurate characterization of the phage. The adsorption curve of MRSA-phage is shown in Figure 3. MRSA phage adsorption achieved $100 \%$ after 35 minutes of exposure to the host bacteria.

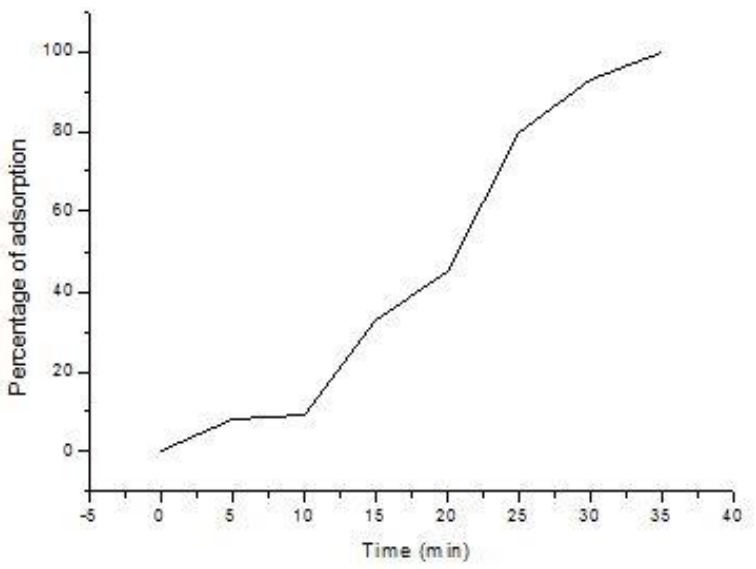

Figure 3 Adsorption curves of MRSA phage.

\section{Phage protein}

The structural protein composition of Staphylococcus phage was analyzed by SDS-PAGE. One major structural protein was detected during the analysis of the phage. Protein profiling can be used as a molecular signature tag of a phage, helping in identifying as well as differentiating it from other phages, as phages even within the same family tend to have different structural proteins owing to differences in phage specificity (Shivu $\boldsymbol{e t}$ al., 2007) as evidenced by the lack of comparable protein profile among phages belonging to Podoviridae family. The structural protein of MRSA-phage was analyzed by SDS-PAGE (Figure 4). It showed that the virions contained one major protein with a molecular weight about of $30 \mathrm{kDa}$.



Figure 4 Sodium dodecyl sulfate-polyacrylamide gel electrophoresis of MRSA phage structural protein. Lanes: M, standard proteins; 1, phage protein, stained with Coomassie blue. The size of the phage proteins is expressed in $\mathrm{kDa}$.

\section{CONCLUSION}

In this study, virulent phage with lytic activity against MRSA strain was isolated. Morphologically, the phage is member of the family Myoviridae, and exhibited an identical host range. Adsorption studies showed $100 \%$ adsorption of MRSA-Phage after 35 minutes of exposure. SDS-PAGE indicated that the phage particles contain one major structural protein (about $30 \mathrm{Kda}$ ). Our results indicated good efficacy for this phage, which consistent with data cited by Kaźmierczak et al., 2014. They studied the phages which able to kill S. aureus in the treatment of various human diseases, e.g., venous leg ulcers and eye infections, septicemia, staphylococcal lung infections, and others. Because there are not enough chemotherapeutics to destroy bacteria and to counteract the problem of infections in the human population, however the field of phage therapy as antibacterial agents has advanced considerably as an alternative to antibiotics (Kwiatek et al., 2012; Chhibber et al., 2008; Kim et al., 2007 and Westwater et al., 2003). Finally, phage treatment may help to reduce the frequency of potentially lethal infections in the hospital environment, with related costs that can be significantly lower than those of antibiotics.

\section{REFERENCES}

ADAMS, M. 1959. Bacteriophages, Interscience Publishers, NY Blackie Academic \& Professional, London.

AL-YOUSEF, S. 2013. Methicillin-Resistant Staphylococcus aureus Phages: Isolation and Identification. Journal of pure and applied microbiology, 7(2), 939945

AMENU, D. 2014. Isolation of Bacteriophages Specific to Escherichia coli, Staphylococcus aureus and Pseudomonas aeruginosa. Bio-Genetics J., 2(1), 32 36.

ASWANI, V., TREMBLAY, D., MOINEAU, S., SHUKLA, S. 2011 Staphylococcus epidermidis Bacteriophages from the Anterior Nares of Humans. Applied and environmental microbiology, 77(21), 7853-7855. http://dx.doi.org/10.1128/aem.05367-11

BARROW, P., SOOTHILL, J. 1997. Bacteriophage therapy and prophylaxis: rediscovery and renewed assessment of potential. Trend Microbiology, 5(7), 268 271. http://dx.doi.org/10.1016/s0966-842x(97)01054-8

BARRY, A. 2007. An Overview of the clinical and laboratory standards institute (CLSI) and its impact on antimicrobial susceptibility tests. Antimicrobial Susceptibility Testing Protocols [Internet]. CRC Press; May 22, 1-6, Available from: http://dx.doi.org/10.1201/9781420014495.ch1

BASEW, I. H., LAING, M. D. 2014. Stress sensitivity assays of bacteriophages associated with Staphylococcus aureus, causal organism of bovine mastitis. African Journal of Microbiology Research, 8(2), 200-210.

BOULANGER, P. 2009. Purification of bacteriophages and SDS-PAGE analysis of phage structural proteins from ghost particles. Methods in molecular biology, 502, 227-238. http://dx.doi.org/10.1007/978-1-60327-565-1_13

CHHIBBER, S., KAUR, S., KUMARI, S. 2008. Therapeutic potential of bacteriophage in treating Klebsiella pneumoniae B5055-meiated lobar pneumonia in mice. J Med Microbiol, 12, 1508-1513.

CLSI, 2013. Performance Standards for Antimicrobial Susceptibility Testing, Twenty-Third Informational Supplement. CLSI document M100-S23. Wayne, PA: Clinical and Laboratory Standards Institute.

CUI, Z., SONG, Z., WANG, Y., ZENG, L., SHEN, W. 2012. Complete genome sequence of wide-host-range Staphylococcus aureus phage JD007. J Virol, 86 13880-13881.

DAVIS, K., STEWART, J., CROUCH, H., FLOREZ, C., HOSPENTHAL, D 2004. Methicillin- resistant Staphylococcus aureus (MRSA) nares colonization at hospital admission and its effect on subsequent MRSA infection. Clinical Infectious Diseases, 39(6), 776-782. http://dx.doi.org/10.1086/422997

DUCKWORTH, D., GULIG, P. 2002. Bacteriophage. BioDrugs, 16(1), 57-62. http://dx.doi.org/10.2165/00063030-200216010-00006

DURMAZ, E. 1992. A fourth mechanism of bacteriophage resistance in Lactococcus lactis subsp. lactis ME2. MS Thesis. NC State University, Raleigh, $\mathrm{NC}$

EL HADDAD, L., BEN ABDALLAH, N, PLANTE,P L., DUMARESQ, J, KATSARAVA, R., LABRIE, S., JACQUES, C., ST-GELAIS, D., MOINEAU, S. 2014. Improving the safety of Staphylococcus aureus polyvalent phages by their production on a Staphylococcus xylosus strain. PLOS ONE, 9(7), 1-10 e102600. doi:10.1371/journal.pone.0102600

FRANCOIS, P., SCHERL, A., HOCHSTRASSER, D., SCHRENZEL, J. 2010. Proteomic approaches to study Staphylococcus aureus pathogenesis. Journal of Proteomics, 73(4), 701-708. http://dx.doi.org/10.1016/j.jprot.2009.10.007

JEVONS, M. 1961. "Celbenin" - resistant Staphylococci. Br. Med. J., 1(5219), 124-125. http://dx.doi.org/10.1136/bmj.1.5219.124-a

GU, J., LIU, X., LU, R., LI, Y., SONG, J. 2012. Complete genome sequence of Staphylococcus aureus bacteriophage GH15. J Virol, 86, 8914-8915.

KAŹMIERCZAK, Z., GÖRSKI, A., DABROWSKA, K. 2014. Facing antibiotic resistance: Staphylococcus aureus Phages as a Medical Tool. Viruses, 6, 25512570. doi:10.3390/v6072551 
KHAIRULDDIN, N., BISHOP, L., LAMAGNI, T., SHARLAND, M., DUCKWORTH, G. 2004. Emergence of methicillin resistant Staphylococcus aureus (MRSA) bacteraemia among children in England and Wales. Archives of $\begin{array}{llll}\text { Disease in } & \text { Childhood, } & \text { 378-379. }\end{array}$ http://dx.doi.org/10.1136/adc.2003.028712

KIM, K. P., KLUMPP, J., LOESSNER, M. J. 2007. Enterobacter sakazakii bacteriophages can prevent bacterial growth in reconstituted infant formula. Int $J$ Food Microbiol, 115, 195-203.

KURLENDA, J., GRINHOLC, M. 2010. Current diagnostic tools for methicillinresistant Staphylococcus aureus infections. Molecular Diagnosis and Therapy, 14, 73-80. http://dx.doi.org/10.1007/bf03256356

KWIATEK, M., PARASION, S., MIZAK, L., GRYKO, R., BARTOSZCZE, M. KOCIK, J. 2012. Characterization of a bacteriophage, isolated from a cow with mastitis, that is lytic against Staphylococcus aureus strains. Arch Virol, 157, 225234

LAEMMLI, U. 1970. Cleavage of structural proteins during the assembly of the heated of bacteriophage T4. Nature, 227(5257), 680-685. http://dx.doi.org/10.1038/227680a0

LESZCZYNSKI, P., WEBER-DABROWSKA, B., KOHUTNICKA, M., LuczakLUCZAK, M., GORSKI, A. 2006. Successful eradication of methicillinresistant Staphylococcus aureus (MRSA) intestinal carrier status in a healthcare worker-case report. Folia Microbiolica, 51(3), 236-238. http://dx.doi.org/10.1007/bf02932128

LI, L., ZHANG, Z. 2014. Isolation and characterization of a virulent SPW specific Staphylococcus aureus from bovine mastitis of lactating dairy cattle. Mol Biol Rep, 41, 5829-5838.

LYON B., SKURRAY, R. 1987. Antimicrobial resistance of Staphylococcus aureus: genetic basis. Microbiol. Rev., 51, 88-134.

MALKE, 1990. J. SAMBROCK, E. F. FRITSCH and T. MANIATIS, Molecular Cloning, A Laboratory Manual (Second Edition), Volumes 1, 2 and 3. 1625 S., zahlreiche Abb. und Tab. Cold Spring Harbor 1989. Cold Spring Harbor Laboratory Press. ISBN: 0-87969-309-6. Journal of Basic Microbiology, 30(8), 623-623. http://dx.doi.org/10.1002/jobm.3620300824

PLATT, R., REYNOLDS, D., PHILLIPS, G. 2003. Development of a nove method of lytic phage delivery by use of a bacteriophage P22 site-specific recombination system". FEMS Microbiology Letters, 223(2), 259-265. http://dx.doi.org/10.1016/s0378-1097(03)00388-4

SCHMIDT, F., SCHARF, S., HILDEBRANDT, P., BURIAN, M., BERNHARDT, J., DHOPLE, V., KALINKA, J., GUTJAHR, M., HAMMER, E. VOLKER, U. 2010. Time-resolved quantitative proteome profiling of hostpathogen interactions: the response of Staphylococcus aureus RN1HG to internalization by human airway epithelial cells. Proteomics, 10(15), 2801-2811. http://dx.doi.org/10.1002/pmic.201000045

SHAO, Y., Wang, I. 2008. Bacteriophage adsorption rate and optimal lysis time Genetics, 180(1), 471-482. http://dx.doi.org/10.1534/genetics.108.090100

SHIVU, M., RAJEEVA, B., GIRISHA, S., KARUNASAGAR, I., KROHNE, G. KARUNASAGAR, I. 2007. Molecular characterization of Vibrio harveyii bacteriophages isolated from aquaculture environments along the coast of India. Environ. Microbiol., 9(2), 322-331. http://dx.doi.org/10.1111/j.14622920.2006.01140.x

SULAKVELIDZE, A., ALAVIDZE, Z., MORRIS, J. 2001. Bacteriophage therapy. Antimicrobial Agents and Chemotherapy, 45(3), 649-659. http://dx.doi.org/10.1128/aac.45.3.649-659.2001

SWIFT, S.M., NELSON, D.C. 2014. Complete Genome Sequence of Staphylococcus aureus Phage GRCS. Genome Announc, 2(2), e00209-14. doi:10.1128/genomeA.00209-14

VAN DEN BERG, S., BOWDEN, M., BOSMA, T., BUIST, G., VAN DIJL, J., VAN WAMEL W., DE VOGEL, C., VAN BELKUM, A., BAKKERWOUDENBERG, I. 2011. A multiplex assay for the quantification of antibody responses in Staphylococcus aureus infections in mice. Journal of Immunological Methods, 365(1-2), 142-148. http://dx.doi.org/10.1016/j.jim.2010.12.013

WESWATER, C., KASMAN, L. M., SCHOFIELD, D. A., WERNER, P> A. DOLAN, J. W., SCHMID, M. G., NORRIS, J. S. 2003. Use of genetically engineered phage to deliver antimicrobial agents to bacteria: an alternative therapy for treatment of bacterial infections. Antimicrob Agents Chemother, 47, 1301-1307.

YAMAMOTO, K., ALBERTS, B., BENZINGER, R., LAWHORNE, L. TREIBER, G. 1970. Rapid bacteriophage sedimentation in the presence of polyethylene glycol and its application to large-scale virus purification. Virology, 40(3), 734-744. http://dx.doi.org/10.1016/0042-6822(70)90218-7 